\title{
PROMISING NEW SALT OF OSELTAMIVIR
}

\author{
A. I. Kalashnikov, ${ }^{1}$ E. G. Sonina, ${ }^{1}$ D. A. Kulagina, ${ }^{1, *}$ S. V. Sysolyatin, ${ }^{1}$ \\ E. A. Prokop'eva, ${ }^{2}$ and E. Yu. Sherstoboev ${ }^{3}$
}

Translated from Khimiko-Farmatsevticheskii Zhurnal, Vol. 55, No. 6, pp. 12 - 15, June, 2021.

Original article submitted April 1, 2021.

A synthetic method for the promising new drug oseltamivir ethoxysuccinate is described in detail. Various conditions for obtaining the target substance are considered. Its complete physicochemical characteristics are given. The obtained agent is shown to be effective against influenza virus A (H1N1)pdm09.

Keywords: oseltamivir salts, antiviral activity.

An epidemic of influenza virus is currently a challenging problem for mankind. Oseltamivir, zanamivir, peramivir, and laninamivir are long-acting neuraminidase inhibitors designed to treat and prevent influenza virus [1]. The mechanism of action of these drugs is based on blockage of the enzyme neuraminidase. Oseltamivir, which is perorally active, is most interesting although it is toxic and has several side effects [2]. Oseltamivir itself and its decomposition products in the gastrointestinal tract (GIT) are responsible for the toxicity [3]. It was assumed that organic salts of oseltamivir could be used to accelerate its absorption in the GIT and thereby reduce its decomposition and; correspondingly, its toxicity.

Therefore, research on the replacement of the phosphate salt by a less toxic salt has become popular. Salts that would be just as potent antivirals, have good water-solubility, and crystallize readily and directly from the reaction mixture have been examined.

The possibility of using several pharmaceutically acceptable oseltamivir salts such as the hydrochloride, hydrobromide, nitrate, sulfate, citrate, formate, fumarate, maleate, acetate, $p$-toluenesulfonate, benzenesulfonate, and glucuronide has been reported $[4,5]$. However, the chemical and physical properties of the above compounds and their biological ac-

${ }^{1}$ Institute for Problems of Chemical and Energetic Technologies, Siberian Branch, Russian Academy of Sciences, 1 Sotsialisticheskaya St., Biysk, Altai Krai, 659322 Russia.

${ }^{2}$ Federal Research Center of Fundamental and Translational Medicine, 2 Timakova St., Novosibirsk, 630117 Russia.

3 E. D. Goldberg Research Institute of Pharmacology and Regenerative Medicine, Tomsk National Research Medical Center, 3 Prosp. Lenina, Tomsk, 634028 Russia.

e-mail: imbiri@rambler.ru tivities were not given. A method for purifying oseltamivir base via formation of its tartrate was described in detail. However, the pharmacological properties of this compound were not disclosed [6].

Oseltamivir phosphate forms upon treatment of oseltamivir base with an equivalent amount of ortho-phosphoric acid in EtOAc. The salt forms in $4-5 \mathrm{~h}$ at reaction temperatures $\leq 45^{\circ} \mathrm{C}$. Then, the product crystallizes in $84 \%$ yield and $98.9 \%$ purity in another $4-5 \mathrm{~h}$ upon slow cooling to room temperature. This process is rather lengthy from a technological viewpoint. Therefore, research was aimed at discovering oseltamivir salts that would not only simplify the formation and isolation of the salt but also preserve the pharmacological properties at the level of oseltamivir phosphate.

The stability of the products is one condition for using oseltamivir salts as pharmaceutical substances. Previously, the oxalate, malonate, maleate, succinate, malate, fumarate, citrate, and ethoxysuccinate salts of oseltamivir were investigated. Their physicochemical stability and preservation of the crystal form and color were evaluated [7]. Oseltamivir ethoxysuccinate was selected for further research based on the obtained results and the biological activity of the compounds that were calculated using the PASS Refinder program [8].

An original method for preparing ethoxysuccinic acid (IV) from maleic anhydride (I) was developed [9] (Fig. 1).

The reaction of $\mathbf{I}$ with aluminum ethoxide $\left[\mathrm{Al}\left(\mathrm{OC}_{2} \mathrm{H}_{5}\right)_{3}\right]$ under these conditions formed intermediate aluminate ester II, which was converted into IV upon treatment first with base and then with acid. The target acid was obtained according to this method in $96 \%$ yield and $99 \%$ purity according to 


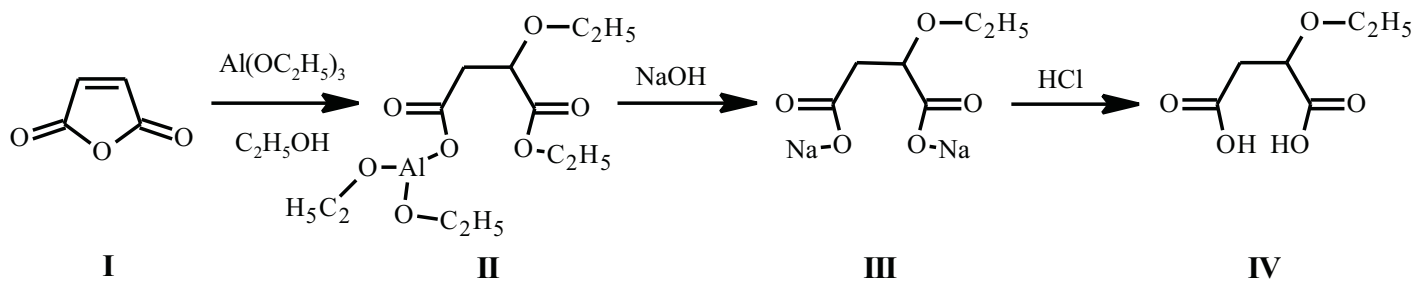

Fig. 1. Scheme for preparing ethoxysuccinic acid.

HPLC. This made the proposed method significantly more efficient than the method using the reaction of diethyl maleate with sodium ethoxide ( $80 \%$ yield) [10].

Oseltamivir salt VI was readily obtained in EtOAc or $\mathrm{Me}_{2} \mathrm{CO}$ at room temperature (Fig. 2). The product precipitated as white crystals from the reaction mixture in $2-4 \mathrm{~h}$ at room temperature and did not require recrystallization. The yield of the crystalline product was $96 \%$ with $99.8 \%$ purity according to HPLC analysis.

The structure of product VI was fully confirmed by physicochemical methods. Its pharmacological potential was demonstrated in comparative tests with Tamiflu ${ }^{\circledR}$. Also, studies of the acute toxicity in the dose range from 500 to $2000 \mathrm{mg} / \mathrm{kg}$ could not determine the $\mathrm{LD}_{50}$ for oseltamivir ethoxysuccinate because large volumes of doses could not be administered and animals in experimental groups did not die. The $\mathrm{LD}_{50}$ lay beyond the limits of the studied doses.

\section{EXPERIMENTAL CHEMICAL PART}

Melting points were determined on a Stuart Model SMP 30 apparatus (England). IR spectra were recorded on an Infralum FT-801 instrument (Russia). PMR and ${ }^{13} \mathrm{C}$ NMR spectra were recorded on a Bruker AM-400 instrument (Germany) at operating frequency $400.13 \mathrm{MHz}$ for ${ }^{1} \mathrm{H}$ and $100.61 \mathrm{MHz}$ for ${ }^{13} \mathrm{C}$. Chromatographic analysis used an Agilent 1200 HPLC with an MS detector (USA). Elemental analyses were performed on a Thermo Finnigan Flash EA 1112 CHNSO elemental analyzer (Italy).

Oseltamivir base was obtained by the literature method [11]. It was crystallized by adding the liquid residue remaining after concentration to the calculated amount of $\mathrm{Et}_{2} \mathrm{O}$ ( $600 \mathrm{~mL}$ of $\mathrm{Et}_{2} \mathrm{O}$ per $100 \mathrm{~g}$ of liquid residue).

\section{Preparation of ethoxysuccinic acid (IV)}

A $700-\mathrm{mL}$ stainless-steel autoclave was loaded with maleic anhydride (127.5 g), aluminum ethoxide ( $84.3 \mathrm{~g})$, anhydrous EtOH $(300 \mathrm{~mL})$, and a magnetic stirrer and sealed. The autoclave was placed into a silicone bath. The stirring and heating were started. The temperature of the silicone bath was raised after $40-60 \mathrm{~min}$ to $132-136^{\circ} \mathrm{C}$. The pressure rose to $4.6 \mathrm{~atm}$. The reaction mixture was held at a pressure $>4.3 \mathrm{~atm}$ for $4 \mathrm{~h}$ and then cooled to $45-50^{\circ} \mathrm{C}$. The autoclave was opened.

The reaction mixture was stirred, treated with a solution of $\mathrm{NaOH}(105.6 \mathrm{~g})$ in distilled $\mathrm{H}_{2} \mathrm{O}(1050 \mathrm{~mL})$, refluxed, and concentrated to a volume of $900-1000 \mathrm{~mL}$ over $2.5 \mathrm{~h}$ by distilling the EtOH. The residue was cooled and adjusted to pH 6-7 using conc. $\mathrm{HCl}(37 \%)$ to afford a suspension that was stirred for $30 \mathrm{~min}$ and filtered to remove $\mathrm{Al}(\mathrm{OH})_{3}$.

The filtrate was treated with conc. $\mathrm{HCl}(222 \mathrm{~mL})$, held at room temperature for $1 \mathrm{~h}$, and evaporated to constant weight.

The obtained residue was treated with dichloroethane $(2100 \mathrm{~mL})$, refluxed for $1.5 \mathrm{~h}$, and filtered. The filtrate was stirred for $14 \mathrm{~h}$. The resulting precipitate was filtered off and dried in air to afford ethoxysuccinic acid (199.4 g), mp $86-88^{\circ} \mathrm{C}$. PMR spectrum $\left(\mathrm{Me}_{2} \mathrm{CO}-\mathrm{d}_{6}, \delta, \mathrm{ppm}\right): 2.04-2.08$ $(\mathrm{m}), 2.60-2.84(\mathrm{~m}), 3.48-3.59(\mathrm{~m}), 3.58-3.78(\mathrm{~m})$, $4.24-4.30$ (m), $8.0-11.0$ (br.s). ${ }^{13} \mathrm{C}$ NMR spectrum $\left(\mathrm{Me}_{2} \mathrm{CO}-\mathrm{d}_{6}, \delta \mathrm{ppm}\right): 14.54 ; 37.31 ; 65.99 ; 74.93 ; 170.86$; 172.18. Empirical formula: $\mathrm{C}_{6} \mathrm{H}_{10} \mathrm{O}_{5}$. Calc., \%: C 44.45; $\mathrm{H}$ 6.22; O 49.34. Found, \%: C 44.53; H 6.18; O 49.29.

\section{Preparation of oseltamivir ethoxysuccinate (VI)}

Ethoxysuccinic acid $(9.1 \mathrm{~g}, 55.8 \mathrm{mmol})$ was dissolved in EtOAc $(150 \mathrm{~mL})$. The resulting solution was treated with a solution of oseltamivir base $(15.8 \mathrm{~g}, 50.75 \mathrm{mmol})$ in EtOAc $(100 \mathrm{~mL})$ and held at $45^{\circ} \mathrm{C}$. The warm solution was filtered

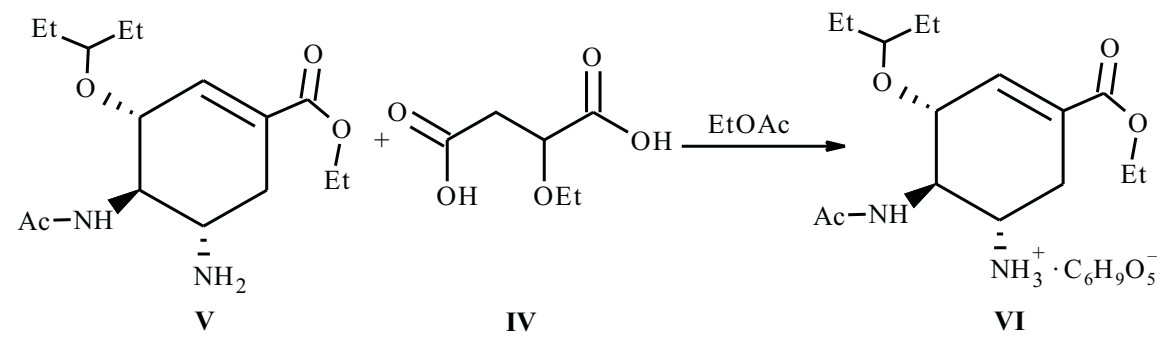

Fig. 2. Scheme for preparing oseltamivir ethoxysuccinate. 
TABLE 1. Comparative Analysis of Experimental Anti-influenza Activities of VI and Tamiflu ${ }^{\circledR}$ in BALB/c Mice Infected with an Adapted Variant of Pandemic Influenza A Virus (H1N1)pdm09

\begin{tabular}{|c|c|c|c|c|}
\hline \multirow[b]{2}{*}{ Parameters } & \multicolumn{4}{|c|}{ Experimental BALB/c mouse groups } \\
\hline & $\begin{array}{l}\text { group } 1, \mathbf{V I}, \\
10 \mathrm{mg} / \mathrm{kg} / \mathrm{d}\end{array}$ & $\begin{array}{l}\text { group } 2, \mathbf{V I} \text {, } \\
20 \mathrm{mg} / \mathrm{kg} / \mathrm{d}\end{array}$ & $\begin{array}{l}\text { group 3, Tamiflu } \\
10 \mathrm{mg} / \mathrm{kg} / \mathrm{d}\end{array}$ & $\begin{array}{l}\text { group 4, Tamiflu }{ }^{\circledR}, \\
20 \mathrm{mg} / \mathrm{kg} / \mathrm{d}\end{array}$ \\
\hline $\begin{array}{l}\text { Appearance of first signs of disease in animals as statistically signifi- } \\
\text { cant body-mass loss (after infection), d }\end{array}$ & 3 & 3 & 3 & 3 \\
\hline Lethal outcomes recorded, $d$ & 9,1011 & 14 & $7,8,11,12,14$ & $8,9,12,13$ \\
\hline Total number of deceased animals & 4 & 1 & 5 & 6 \\
\hline Lethality, \% & 13.3 & $3.3^{\#}$ & 16.7 & 20 \\
\hline Survival, $\%$ & 86.7 & $96.7^{\#}$ & 83.3 & 80 \\
\hline
\end{tabular}

Note: ALS, average lifespan; ${ }^{\#}$ statistically significant difference between groups VI $(20 \mathrm{mg} / \mathrm{kg} / \mathrm{d})$ and Tamiflu ${ }^{\circledR}(20 \mathrm{mg} / \mathrm{kg} / \mathrm{d})\left(\chi^{2}\right.$-criterion $)$; Mann-Whitney criterion.

through a Schott glass filter under vacuum. The filtrate was stirred for $16 \mathrm{~h}$. The resulting precipitate was filtered off and dried in air to afford ethyl $(3 S, 4 R, 5 S)$-4-acetamido-5-amino3-(1-ethylpropoxy)cyclohex-1-ene-1-carboxylate ethoxysuccinate as white crystals with $\mathrm{mp} 108-110^{\circ} \mathrm{C}$. PMR spectrum (DMSO-d $\left.\mathrm{D}_{6} \delta, \mathrm{ppm}\right): 0.77-0.85(\mathrm{~m}) ; 1.04-1.09(\mathrm{~m})$; $1.20-1.25(\mathrm{~m}) ; 1.34-1.43(\mathrm{~m}) ; 1.87(\mathrm{~s}) ; 2.26-2.39(\mathrm{~m})$; $2.50-2.57(\mathrm{~m}) ; 2.77(\mathrm{dd}) ; 3.20-3.27(\mathrm{~m}) ; 3.31-3.39(\mathrm{~m})$; $3.57-3.63(\mathrm{~m}) ; 3.71-3.78(\mathrm{~m}) ; 4.13-4.18(\mathrm{~m}) ; 6.65(\mathrm{~s})$; 8.11 (d). ${ }^{13} \mathrm{C}$ NMR spectrum (DMSO-d $\left.6, \delta, p p m\right): 9.33 ; 9.83$; $14.51 ; 15.67 ; 23.65 ; 25.53 ; 26.08 ; 29.19\left(\mathrm{CH}_{2}\right) ; 29.22$; $49.35 ; 53.14 ; 64.87 ; 74.65 ; 76.21 ; 81.65 ; 127.65 ; 138.81$; 165.58; 172.95; 174.92. Empirical formula: $\mathrm{C}_{16} \mathrm{H}_{28} \mathrm{~N}_{2} \mathrm{O}_{4} \cdot \mathrm{C}_{6} \mathrm{H}_{10} \mathrm{O}_{5}$. Calc., \%: C 55.64; H 8.01; O 5.90. Found, \%: C 55.64; H 7.93; N 6.01 .

\section{EXPERIMENTAL BIOLOGICAL PART}

The therapeutic effect of VI was comparatively assessed using Tamiflu ${ }^{\circledR}$ as a reference drug to treat BALB/c inbred mice infected with influenza induced by an adapted variant of the pandemic influenza A virus (H1N1)pdm09. Virus containing MA1-BALB/c strain material was produced. $\mathrm{LD}_{50}$ values were determined to calculate the working dose for infecting the experimental mice. The doses of the administered drugs for the experimental animals were determined.

\section{EXPERIMENTAL ANIMAL GROUPS}

The experiments used 140 female BALB/c mice aged $6-8$ weeks $(18-24 \mathrm{~g})$. The mice were kept under standard vivarium conditions at $18-26^{\circ} \mathrm{C}$ with a $12: 12$-h (day-night) lighting regime in plastic cages (Velaz). The mice were divided into six groups. Group 1 (30 animals) received intragastrically oseltamivir ethoxysuccinate $(10 \mathrm{mg} / \mathrm{kg} / \mathrm{d})$ in distilled $\mathrm{H}_{2} \mathrm{O}(200 \mu \mathrm{L})$. Group 2 (30 animals) received intragastrically oseltamivir ethoxysuccinate $(20 \mathrm{mg} / \mathrm{kg} / \mathrm{d})$ in distilled $\mathrm{H}_{2} \mathrm{O}(200 \mathrm{~mL})$. Group 3 (30 animals) received intragastrically Tamiflu ${ }^{\circledR}(10 \mathrm{mg} / \mathrm{kg} / \mathrm{d})$ in distilled $\mathrm{H}_{2} \mathrm{O}$ $(200 \mu \mathrm{L})$. Group 4 (30 animals) received intragastrically Tamiflu $^{\circledR}(20 \mathrm{mg} / \mathrm{kg} / \mathrm{d})$ in distilled $\mathrm{H}_{2} \mathrm{O}(200 \mu \mathrm{L})$. Group 5 (10 animals) acted as a negative control and did not receive a drug. Group 6 (10 animals) acted as a positive control, was not infected, and received intragastrically distilled $\mathrm{H}_{2} \mathrm{O}$ $(200 \mu \mathrm{L})$. The drugs and solvent (distilled $\left.\mathrm{H}_{2} \mathrm{O}\right)$ were administered to the mice $5 \mathrm{~d}$ after infection.

\section{EXPERIMENTAL MODEL}

Mice of groups $1-5$ were infected intranasally with an adapted variant of the pandemic influenza $A$ virus (H1N1)pdm09 deposited in GenBank under the name A/Tomsk/273-MA1/2010(H1N1pdm09) (MA1-BALB/c) (KM277585-KM277592) at a dose of 10 LD $_{50}$ in phosphate buffered saline (PBS, $50 \mu \mathrm{L}$ ). Mice of group 6 were administered intranasally PBS $(50 \mu \mathrm{L})$. Mice of groups $1-4$ were administered the drugs after $2 \mathrm{~h}$; of group 6 , distilled $\mathrm{H}_{2} \mathrm{O}$. The animals were observed for $14 \mathrm{~d}$, during which their behavior and appearance were assessed, body mass was measured, body temperature in an ear canal was measured in ${ }^{\circ} \mathrm{C}$ using a Thermoval duo scan infrared electronic thermometer (Hartmann), the number of deceased mice was counted, and the average lifespan (ALS) was estimated. 


\section{RESULTS AND DISCUSSION}

Table 1 compares the characteristics of the therapeutic effects of VI and Tamiflu ${ }^{\circledR}$ (oseltamivir phosphate) for treating influenza infection of BALB/c laboratory mice induced by an adapted variant of pandemic influenza $A$ virus (H1N1)pdm09.

An analysis of the series of experimental results found that:

the first signs of the disease in the animals as a statistically significant body-mass loss was recorded uniformly on the third day in all four experimental groups;

the greatest body-mass loss of the animals during the experiment was observed for group 1 that received VI $(10 \mathrm{mg} / \mathrm{kg} / \mathrm{d})$; the lowest body-mass loss, group 2 (VI, $20 \mathrm{mg} / \mathrm{kg} / \mathrm{d}$ ) and group 3 that received Tamiflu ${ }^{\circledR}$ (10 mg/kg/d);

the largest number of lethal outcomes among the experimental animals was recorded for group 4 that received Tamiflu $^{\circledR}(20 \mathrm{mg} / \mathrm{kg} / \mathrm{d})$ and was 6 of 30 infected animals; the smallest number, for group 2 that received VI $(20 \mathrm{mg} / \mathrm{kg} / \mathrm{d})$ and was 1 of 30 infected animals;

the longest ALS among the four mouse groups infected with $10 \mathrm{LD}_{50}$ by strain MA1-BALB/c was noted for group 2 that received VI $(20 \mathrm{mg} / \mathrm{kg} / \mathrm{d})$ and was $13.97 \pm 0.03 \mathrm{~d}$; the shortest ALS among infected mice, group 3 that received Tamiflu $^{\circledR}(10 \mathrm{mg} / \mathrm{kg} / \mathrm{d})$ and was $12.97 \pm 0.42 \mathrm{~d}$. The ALS of the negative control group that did not receive the anti-influenza drugs was $8.30 \pm 0.62 \mathrm{~d}$;

the lowest percent survival was noted for group 4 (Tamiflu $^{\circledR}, 20 \mathrm{mg} / \mathrm{kg} / \mathrm{d}$ ) and was $80 \%$; the highest percent survival, group 2 (VI, $20 \mathrm{mg} / \mathrm{kg} / \mathrm{d}$ ) and was $96.7 \%$.
Thus, the antiviral effect of oseltamivir ethoxysuccinate was found to be comparable to that of widely used oseltamivir phosphate. The new drug exhibited lower toxicity. The results allowed the new drug to be considered a promising compound for further studies and for designing a new antiviral agent based on it.

\section{REFERENCES}

1. P. Laborda, S. Wang, and J. Voglmeir, Molecules, 21, 1513 (2016).

2. T. Jefferson, V. Demicheli, C. Pietrantonj, et al., Cochrane Database Syst. Rev., No. 3, 1265 (2006).

3. T. Jefferson, M. A. Jones, P. Doshi, et al., Cochrane Database Syst. Rev., No. 3, Art. CD001265 (2006); No. 4, Art. CD008965 (2014).

4. K. M. Kent, C. U. Kim, et al., Int. Pat. WO 1998007685, Feb. 26, 1998; Byull. 60 / 024,122 (1998).

5. A. Sugiyama, US Pat. Appl. 20140051756, Feb. 20, 2014; Byull. 14 / 062,174 (2014).

6. R. B. Parthasaradhi, R. K. Rathnakar, et al., Int. Pat. WO 2007077570 A1, Jul. 12, 2007; Byull. 2006 / 000001 (2007).

7. E. G. Sonina, A. I. Kalashnikov, D. A. Kulagina, and A. S. Goryaev, Yuzhn.-Sib. Nauchn. Vestn., No. 4, $161-165$ (2019).

8. D. A. Filimonov, D. S. Druzhikovskiy, A. A. Lagunin, et al., Biomed. Chem.: Res. Methods, No. 1, 1 - 21 (2018).

9. A. I. Kalashnikov, S. V. Sysolyatin, and E. G. Sonina, RU Pat. 2,668,548, Oct. 2, 2018; Byull. No. 28 (2018).

10. T. Purdie and J. Irvine, J. Chem. Soc., 83, 1021 - 1037 (1903).

11. A. I. Kalashnikov, S. V. Sysolyatin, G. V. Sakovich, et al., Russ. Chem. Bull., No. 1, 163 - 170 (2013). 